\section{Editorial/Éditorial}

\section{The National Forest Congress}

The National Forest Congress has come and gone. Its proceedings will appear in English in the Forestry Chronicle and in French in Forêt Conservation. In this issue, Dr. R.J. Bourchier outlines the program and gives his impressions of the Congress. My impressions were somewhat different.

Many of the papers were excellent. Discussion following the presentations was frequently stimulating. I have never before sat through so rivetting a forestry session as that staged by the "BC talent show" on employment. Jack Webster was outstanding as the provocative chairman. No one could fail to be moved by Jack Munro's passionate indictment of a "heartless" industry for its indifference to the plight of longterm employees laid off with a minimum of benefits. Equally moving in a different way was Graham Bruce's exhortation to carry the story of forestry to the public - how he lost an election for MLA in British Columbia l'll never understand. Unfortunately, these two latter messages will probably never appear in print because both speakers abandoned their scripts.

As Bob Bourchier points out in his paper, events like the Congress seldom produce dramatic break-throughs, but are valuable in raising the consciousness of the public and politicians on the importance of good forestry and in providing reference points on the road to responsible forest management. $\mathrm{He}$ is right. Nevertheless the end of the Congress left me with a feeling of disappointment. This is why.

The Prime Minister opened the first session on trade with a polished and amusing address. But he said nothing new no mention of a federal Department of Forestry that we all were waiting for. (We shall have to push hard during the next few months if we wish to see that.) There was almost an element of intellectual dishonesty in the way he and other ministers bandied impressive figures for expenditures on forest management without once mentioning that these were to be spread over five years.
In the same session, everyone seemed to express grave concern over Canada's falling share of world markets in forest products. As the size of the world market grows and more countries get into the act, Canada's percentage share must inevitably fall. What counts is that we maintain or increase the absolute amount of our exports and that we can sell them at a profit - but no one said that.

In discussing wood supply, some members of industry still seemed to question whether Canada has a problem, although this has been documented to death. And I become very tired of hearing industry officials moan that they cannot be expected to invest in forestry when they lack security of tenure. This is a red herring. In most of Canada, big industry has security of tenure as long as it lives up to the terms of its license agreements.

There was a conspicuous absence of tough questions thrown at the panels, particularly the panel of forestry ministers, which almost sounded like a love-in. For example, all agreed that more R \& D is a must, but no one asked why government and industry aren't hiring more researchers. Again, better forest management is a must, but where are the foresters and technicians in the woods to make it possible? The provinces have reduced rather than increased forestry staff and no one questioned industry's deplorable hiring record in light of its increasing management responsibilities.

I was also disappointed in the Congress' publicity. At most meetings of this importance, there is usually a continuing flow of press releases. I don't recall having seen any at the Congress despite a firm having been hired to handle publicity. And I hardly saw a mention of the meeting in the Ottawa Citizen, Globe and Mail or the Montreal Gazette.

I hope the Congress will prove to be the milestone that its organizers and participants expected. But unless the forestry world maintains and increases its efforts to carry the forestry story to government and the public, I fear that it will have no more impact than the 1966 Montebello Conference.

I.C.M. Place

\title{
Forest Policy Developments
}

\section{New Forestry Legislation Introduced in Nova Scotia}

On 3 February, 1986, the Honourable Kenneth Streatch, Minister of Lands and Forests, announced a new forest policy for Nova Scotia, based largely on the recommendations of the Nova Scotia Royal Commission on Forestry. ${ }^{1}$ On 17 April, he tabled three new bills in the Provincial Legislature to implement the new policy. These new bills are the 'Forest Enhancement Act', the Forests Act and the Act to Establish the Nova Scotia Primary Forest Products Marketing Board.

See The Forestry Chronicle 62(2): 76-78

\section{Forest Enhancement Act}

The umbrella legislation for the new forestry policy is the Forest Enhancement Act. Replacing the Forest Improvement Act, this is designed to:

- develop a healthier, more productive forest;

- support private landowners in making the most productive use of their woodlands; 